Christina Hedman* and Ulrika Magnusson*

\title{
Adjusting to linguistic diversity in a primary school through relational agency and expertise: a mother-tongue teacher team's perspective
}

\author{
https://doi.org/10.1515/multi-2021-0070
}

Received June 15, 2021; accepted January 18, 2022; published online February 4, 2022

\begin{abstract}
This paper explores the role of collaborative teacher agency in facilitating translingual adjustments in a linguistically diverse primary school in Sweden. We focus on three multicompetent language teachers, who taught minoritized languages in the marginalized Mother Tongue (MT) subject, Modern Languages, and offered Multilingual Study Mentoring. Drawing from ethnographic fieldwork, including teacher interviews and fieldnotes from everyday MT practices and preparations for an annual musical performance, we investigated how the teachers adjusted to the students' multilingual repertoires through relational agency and distributed expertise (Edwards, A. 2011. Building common knowledge at the boundaries between professional practices: Relational agency and relational expertise in systems of distributed expertise. International Journal of Educational Research 50(1). 33-39). These adjustments affected the offered language provisions beyond what was required, based on students' linguistic competencies and parental involvement. Didactic adjustments also afforded migrant students literary experiences that starkly contrasted with the limited literacy content in beginner courses in Swedish. These "responsive professional actions" (Edwards, A. 2011. Building common knowledge at the boundaries between professional practices: Relational agency and relational expertise in systems of distributed expertise. International Journal of Educational Research 50(1). 33-39, p. 39) thus impacted on the students' opportunities for multilingual development, expanded
\end{abstract}

Christina Hedman and Ulrika Magnusson contributed equally to this study.

*Corresponding authors: Christina Hedman and Ulrika Magnusson, Department of Teaching and Learning, Stockholm University, 10691 Stockholm, Sweden, E-mail: christina.hedman@su.se (C. Hedman), ulrika.magnusson@su.se (U. Magnusson). https://orcid.org/0000-0001-88696687 (C. Hedman), https://orcid.org/0000-0002-8887-0590 (U. Magnusson)

Ә Open Access. ( 2022 Christina Hedman and Ulrika Magnusson, published by De Gruyter. (cc)BY This work is licensed under the Creative Commons Attribution 4.0 International License. 
language registers, including verbal art, and linguistic inclusion. Through these actions, language was reformulated as asset, and we find that an ethics of care (Watkins, M. 2011. Teachers' tears and the affective geography of the classroom. Emotion, Space and Society 4(3). 137-143) was closely intertwined with this relational agency. The findings contribute new knowledge on the role of collaborative teacher agency in diverse settings also of relevance to other national contexts.

Keywords: linguistic inclusion; literature; mother tongue instruction; multilingualism; relational agency

\section{Introduction}

The role of human agency within societal structures and institutions is an old issue in social theory (e.g. Giddens 1984). Several scholars have argued that agency is not only a capacity of the individual, but may also be collaborative and relational (e.g., Edwards 2005, 2011). When focusing on teacher agency, we also need to ask to what extent teachers have the power to act, as agency is contingent upon the ecology of the educational milieu (see Priestly et al. 2015).

In this paper, we attend to both the role of relational agency and relational expertise (Edwards 2005, 2010, 2011) for promoting translingual adjustments among multilingual Mother Tongue (MT) teachers at a linguistically and culturally diverse primary school in Sweden. By drawing on ethnographic fieldwork, a focus on relational expertise in and across various language disciplines allows us to direct our attention to the teachers' "capacity for working with others" (Edwards 2011: 34) with regard to an educational objective. This is in line with "the relational turn in expertise" (Edwards 2010).

More specifically, a focal point is on how the teachers collaboratively facilitated translingual adjustments, language learning and access to literary texts for migrant primary school children. We found it particularly interesting to explore this type of collaborative agency in a school where a large proportion of the children and their families had been forced to migrate, and how their trajectories of vulnerability spurred responses among the teachers (see Edwards 2011: 33). The relatively unique condition that the school had three locally employed Mother Tongue (MT) teachers also attracted our attention, as MT teachers often ambulate between schools, with weak anchoring at the schools as a result (cf. Ganuza and Hedman 2015). From an international perspective, this focus provides insight into how relational agency, within a specific ecology, can enable adjustments to the needs of multilingual and newly arrived children. 


\subsection{The school-subject mother tongue, modern languages and multilingual study mentoring}

The right to MT instruction is stated in the Swedish Education Act. A student is entitled to MT instruction if the parent/caregiver speaks a language other than Swedish on a daily basis and the student has basic competence in that language. ${ }^{1}$ A student can only study one language in MT (Ministry of Education and Research 2010).

Several languages can be studied either within MT or as a Modern Language (ML), where the latter is, as opposed to MT, a mandatory subject for all students that also adheres to its own syllabus. Each school decides which languages to offer as ML, but two of these languages must be French, German or Spanish. Students earn grades from grade 6 (ages 11-12).

Although the MT subject has strong legal support, it suffers from long-term implementation issues. Apart from being non-mandatory, the MT subject lacks a guaranteed teaching time, resulting in only about 40 min of lessons per week (Ganuza and Hedman 2015; SOU 2019:18). In addition, MT teachers frequently ambulate between several schools, often after regular school hours. The MT subject is thus a marginalized teaching practice (Ganuza and Hedman 2015; Straszer and Wedin 2020). This marginalization is, however, not merely organizational, but may be seen as relating to power dynamics and language hierarchies (cf. Hult 2012). As Janks (2013: 226) points out, there may be a diversity of languages and literacy, but "not all discourses/genres/languages/literacies are equally powerful".

Recently arrived migrant students also have the right to be scaffolded by $a$ multilingual study mentor (often named study guide) who helps students who "cannot follow teaching in Swedish" (Swedish National Agency for Education 2019). Multilingual study mentoring is thus language support offered in the language that is considered to be the student's "strongest language" as a way of promoting subject learning in Swedish (Swedish National Agency for Education 2019). This service is often provided by MT teachers (see also Rosén et al. 2020).

A recent overview of research relating to the MT subject (SOU 2019:18), shows a focus on the aforementioned implementation problems as well as other challenges related to the teaching of a heterogeneous student group. Also, teachers' and parents' perceptions of MT have been explored, as well as didactic aspects of multilingual study mentoring. However, there is a lack of studies exploring the role of an MT teacher team for students' learning. Such locally employed teams are also uncommon in schools, reflecting the marginalization of the MT subject. We find

1 This restriction does not apply to the national minority languages. 
that a focus on teachers, who collaboratively work towards a more central position in the school's ecology, building on a joint vision of widened opportunities for migrant learners, is relevant also from an international perspective.

\subsection{Translingual adjustments and engagement with literature}

When scrutinizing the role of the relational agency and expertise of these locally employed MT teachers, we build on observations from their MT classes, as well as informal discussions and audio-recorded interviews with the teachers, with a special focus on how they prepared for an annual musical performance for International Mother Language Day (UNESCO ${ }^{2}$ ).

Our aim was to highlight the significance of the teachers' collaboration and discuss how it enabled various adjustments in relation to language educational provisions. We were thus interested in how the migrant students' multilingual repertoires were accounted for in this social space. Building on a contact zone perspective (Pratt 1991), we adhere to a dynamic view of social spaces as "open to the mixing and merging of diverse norms" (Canagarajah and Matsumoto 2017: 391f). We interpret such a dynamic view of social and linguistic space - in line with a translingual lens (cf. Canagarajah and Matsumota 2017) - as a critical approach that seeks to obtain respect for linguistic diversity in deliberate ways (cf. Horner et al. 2011: 305). A translingual approach may also encompass a critical examination of "legitimate language/s" in a certain setting (Bourdieu 1977), here understood as legitimate languages or as registers or styles. Importantly, in a school's practiced language policy, languages, or language varieties, may be acknowledged as legitimate, while at the same time they may be treated as less valued within "top-down language policies and ideologies held at the societal and institutional levels" (Bonacina-Pugh 2020: 434; also Bonacina-Pugh 2012). This may imply a flexibility and adaptability in relation to students' multilingual repertoires in terms of educational provisions. We consider the potential of such local policies to create space for multilingual practices, teaching and learning as a function of teacher agency within a specific educational context.

Another aim was to scrutinize how the MT subject and collaboration between the teachers provided multilingual students with experience in text and registers, including the language of literature (Miller and Turci 2007). This is in line with the fact that schooling entails encounters with "written educational knowledge" and reinterpretation "of experience in the new mode of written language" (Halliday 1993: 109) in semiotic contexts. Our interest concerns, for example, the extent to

2 https://en.unesco.org/commemorations/motherlanguageday. 
which such experiences are afforded students by MT teachers through languages other than Swedish, particularly with respect here to the teaching of literature and poetry. We recognize the reading of literature as a value in its own right, but also rely on research showing how reading literature may impact children's emotional and cognitive development (e.g., Nikolajeva 2014), as well as autonomy and emancipation (Nussbaum 1997). Research has also shown how the language and literacy that students encounter in school (cf. the notion of uncommon sense registers, Halliday 1993) may be particularly effective for school achievement when taught (also) in students' strongest languages (e.g., Thomas and Collier 2002; cf. Ganuza and Hedman 2019). We are thus also interested in the type of literature experiences offered in the MT subject.

More specifically, we aim to discuss how adjustments were made at the following levels: (i) a language provision level regarding how language educational provisions were adapted to the students' multilingual repertoire (see Adjustments to the students' multilingual repertoire below); (ii) a classroom level, regarding, for example, didactic adjustments to various language proficiency levels (see Didactic adjustments, below); and (iii) adjustments with respect to an ethos of inclusion, through various means, or strategies, including linguistic inclusion and parental involvement (see Adjustments with respect to an ethos of inclusion below). By linguistic inclusion, we target the recognition and use of students' multilingual repertoires.

However, a translingual approach manifests itself in ways other than the mere celebration of linguistic diversity (cf. Janks 2013), for example, through deliberate and long-term strategies for linguistic inclusion. Block et al.'s (2014) “ethos of inclusion and celebration of cultural diversity" (p. 1340) comprise several strategies, inter alia, employing staff from linguistically diverse backgrounds. Such ethos also encompasses an accommodation of "diverse voices and perspectives so that all children feel they belong and can contribute" (Block et al. 2014: 1340; Taylor and Sidhu 2012). Moreover, we find that an ethos of inclusion is closely tied to "an ethics of care" (Watkins 2011), since the deliberate acts of inclusion outlined above also involve emotive aspects. This will be discussed further in relation to the MT teacher team.

\subsection{Relational agency and distributed expertise}

As we discuss how these adjustments were accomplished on the basis of relational agency among the MT teachers, we also need to understand how agency relates to expertise (Edwards 2011). Edwards (2011) notes that teacher expertise forms part of "local systems of distributed expertise" in schools (p. 33) that may be "distributed 
across practices and settings" (p. 33). This kind of distributed expertise is evident among the teachers of the current paper, who both taught MT language classes in the students' various languages and worked with multilingual study mentoring; two of them also taught Romance languages as a Modern Language. Hence, their expertise differed with respect to language competences and teaching practices. Further, according to Edwards (2011), relational expertise concerns countering complex problems through both collaborating with others and understanding and bringing in the interpretations of other professionals into one's own. This, Edwards claims, is done without devaluating one's expertise but understanding other professionals' practices and areas of expertise. An important feature of collaboration is thus an openness to learn from practice and a focus on the whole child (p. 35). This kind of collaboration may lead to shared knowledge and a readiness to formulate new visions and solutions to complex problems. Such a "responsive professional action" (p. 39) includes "possibilities which go beyond present actualities" (Wartofsky 1973, in Edwards 2011: 36) and the envisionment of "an imagined world" in professional, collaborative encounters (p. 36). Relational collaboration may thus foster envisioned future possibilities and new alternatives, i.e., hinging on "tertiary artefacts" (p. 38), which may also entail the dismantling of existing practices or categorizations (cf. status quo as "secondary artefacts”, p. 38). Here, we focus on the MT teachers' visions of language education in terms of adjustments for linguistic and epistemic access and of inclusion, in relation to children in trajectories of vulnerability and forced migration. A question that arises is how these practices can foster multilingualism and scaffold learning in minoritized languages from a language as a right and a resource perspective (Ruíz 1984).

\subsection{The study}

\subsubsection{A linguistic ethnographic approach at Chestnut}

This study uses a linguistic ethnographic lens (see Copland and Creese 2015), building on fieldwork from 2016 to 2019 at Chestnut, ${ }^{3}$ a primary suburban school located in a migrant-dense socioeconomically vulnerable area. This school was selected because it had long-term experience catering to a large proportion of migrant students. Almost all students at Chestnut were eligible for MT, suggesting that they spoke more than Swedish at home. We collected data intermittently,

3 All names are pseudonyms. 
focusing mainly on three specific practices in three rounds of data collection in line with topic-oriented ethnography (Shaw et al. 2015: 7-8):

(1) 2016-2017: Introductory Classes (ICs), aimed at recently arrived students and a class in Swedish as a second language (SSL), c. 10-15 students in each class (fieldnotes; four audio-recorded interviews with teachers in IC/SSL and MT, and the school principal, c. 60 min each, see Hedman and Magnusson 2021a);

(2) 2018-2019: MT classes (c. 5-15 students in each class) and their work on a musical performance (fieldnotes; two audio-recorded interviews and a 'walking tour' with MT teachers, c. 60 min each); and

(3) 2019: two parenting courses, conducted by the MT teachers (fieldnotes, see Hedman and Magnusson 2021b).

Fieldnotes were collected from class observations (IC, SSL, MT, parenting courses) and related events (during breaks with teachers and students, work on the music performance, interviews), corresponding to c. $80 \mathrm{~h}$ (round 1: c. $30 \mathrm{~h}$; round 2: c. $30 \mathrm{~h}$; round 3: c. $20 \mathrm{~h}$ ).

In this paper, we focus on the collaboration of the MT teachers in relation to their students' language learning, as manifested in overall planning and their joint work on a musical performance, as well as on their flexible and agentive approach to the students' languages. The musical performance, in which the participants were students from different MT classes and ICs, caught our interest, since the preparations involved joint efforts of several teachers and work on advanced literary content. We observed these aspects primarily in the second round of data collection. Hence, the data from the first and third rounds are backgrounded, but still relevant, as these data exemplify other types of collaboration and contribute to our understanding of the role of the MT teachers and the local ecology at Chestnut.

The three participating MT teachers were Omid, Malika and Elena. Omid had worked at Chestnut for many years, whereas Malika and Elena had worked at Chestnut for a relatively short amount of time but had experience as MT teachers at other schools. Omid and Malika, proficient in different Arabic varieties, taught Arabic in MT, while Malika and Elena taught several Romance languages for both MT and ML. Classes in MT and ML generally ranged from c. 5-15 students, with slightly more in some ML classes. The MT teachers also worked as study mentors in the ICs and organized parenting courses aimed at recently arrived migrant parents, which provided ample examples of the role of MT teachers in school-home collaboration (Hedman and Magnusson 2021b). The most experienced MT teacher, Omid, was a "first teacher". This position was held by one teacher per subject and meant that he coordinated the comparatively large group of approximately 25 ambulating MT teachers of various languages working part-time at Chestnut. 


\subsubsection{Fieldnotes, audio-recorded interviews and analytical procedures}

As stated, we build on observational fieldnotes as an important source of data (Blackledge and Creese 2017). Creese et al. (2015) grant these resources a status equal to that of other interactional data in ethnography and contend that "[i]n writing fieldnotes, ethnographers engage in observation, choosing to describe what appears significant to participants" (p. 267).

On most visits, both researchers took fieldnotes, and these were shared shortly afterwards. No observational sheet was used, but a focus was on the teaching as an interactional practice and on reflections from our visits (see Emerson et al. 2011). Both researchers are mother tongue speakers of Swedish who know enough Spanish to be able to follow Spanish MT classes. The fieldnotes in Elena's classes thus represent a mix between Spanish and Swedish, in line with the use of these languages in the classes. As neither of the researchers speaks Arabic, the Arabic teachers regularly explained in Swedish what had been just said in the language. Arabic and Swedish were both used in these classes.

This paper also builds on the MT teachers' expressed views of their work through audio-recorded interviews (Elena and Omid) and an audio-recorded "walking tour" (cf. Szabó 2015). In this tour, Malika guided us around the Arabic MT classroom, displaying her teaching materials and providing the rationale of her selections. The excerpts in this paper have been translated from Swedish to English (for original versions, see Appendix).

The initial multiple readings and sorting of fieldnotes and transcriptions were carried out independently, and were subsequently jointly discussed by us researchers. Thus, all data sets were thoroughly reviewed (cf. Copland and Creese 2015). A focus was on the teachers' joint and individual adjustments to their students, still, with an openness to what appeared in the data. Importantly, we discussed data continuously during fieldwork, which enabled us to identify common foci and to reach convergence in our analysis. First, we inductively identified three levels of analyses - a language provision level, a classroom level and a language ideology level - followed by an abductive phase, where data were theoretically conceptualized in terms of relational agency and distributed expertise, and a framing of language ideology and linguistic adjustments, in relation to the three levels. Performing this analysis would allow us to map out how the collaborative agency of the teacher team enabled linguistic adjustments, as well as inclusion.

The findings are presented and discussed under the three headings below in accordance with the aim of the study. We conclude the article with a discussion of the significance of this MT teacher team at Chestnut in terms of linguistic diversity and opportunities for multilingual language education and development. 


\subsubsection{Adjustments to the students' multilingual repertoire}

From both observations and interviews, it was clear that the three MT teachers jointly strived to adjust to the multilingual repertoires of the migrant students, thus engaging in "responsive collaboration" on a complex phenomenon (Edwards 2011: 33). They told us about typical cases, where, for example, a student of Arabic-speaking parents had also, due to migration, learned Spanish, Greek or Italian. The MT teachers were ready to adjust to these conditions by exploiting their own language competencies. In excerpt 1, Malika gives examples of the MT teachers' adjustments.

Excerpt 1: $\quad$ Audio-recorded researcher talk with Malika (from the classroom walking tour; March 19, 2019).

Researcher: Are there examples of when it has become different, study guidance in one language and mother tongue instruction in another, for the same student?

Malika: There is in Arabic, a lot.

Researcher: Tell us about it.

Malika: We have [student's name], for example; he came to us as newly arrived, and he knows a lot of Swedish because he's also been in the intro [IC] in Swedish as a second language. So now we give him English and Arabic because he knows so much English, so both [laughs] because he can't understand social sciences and natural sciences in Swedish, so we give study guidance in other languages.

Researcher: Both in Arabic and English?

Malika: Yes.

Researcher: Do you do this?

Malika: $\quad$ Me and Omid, I don't have so much time now. [...]

Researcher: But does he then study Arabic in Mother Tongue?

Malika: He comes to Mother Tongue in Arabic, and he also comes to Mother Tongue in English if he has time.

Researcher: Ah both, can he do that?

Malika: $\quad$ Yes, I also have one from [Arabic-speaking country]; he comes to Arabic and French Mother Tongue classes.

Researcher: But that's great, then you think that's...

Malika: I told him if you go to [name of country], Arabic is not enough, because all papers and signs, and people also mix a lot with French. You need two. [laughs] 
Researcher: Ah well.

Malika: $\quad$ So, I said you can come to me [to MT classes in French].

Based on the multilingual repertoire of the recently arrived student in excerpt 1 , Malika and Omid arranged for MT in Arabic, English and French, which was beyond what they were obliged to provide. Their collaboration also entailed greater flexibility than assumed in the legal framework, as only one language should be provided and graded within MT (Ministry of Education and Research 2011). According to Malika, this dilemma was solved by grading only one language (interview; cf. new solutions in terms of tertiary artefacts, Edwards 2011). The motivation for these extra language-educational provisions was their belief that students would benefit from further developing their whole multilingual repertoire. This shared view included distributed expertise, since the MT teachers enabled multilingual development by building on their own existing teaching and language competencies (Edwards 2005, 2011). This is indicative of a collaborative agency that spurred students to study more languages.

Elena told us about similar adjustments and, as in excerpt 2, about flexibility to modify initial plans when they did not work as expected.

Excerpt 2: $\quad$ Fieldnotes from conversation with Elena (February 14, 2019).

Elena tells about the students who have Arabic-speaking parents but who have Spanish MT and study guidance. A boy had both MT Arabic and Spanish last autumn. But since they have [a certain] dialect, the boy does not understand Malika or Omid, according to Elena, so the parents want him to continue with Spanish. The father has apparently lived several years in Spain, so the parents speak Spanish, but not Swedish.

Excerpts 1-2 illustrate how the MT teachers negotiated with parents and students about what language instruction should be offered, indicating a close schoolhome collaboration (cf. Hedman and Magnusson 2021b). In excerpt 2, the negotiation concerned the fact that Omid and Malika, despite understanding several Arabic dialects, did not speak the same variety as this student. As a way of adapting to the student, he thus continued in MT Spanish. This negotiation implies an envisionment of new possibilities (Edwards 2011), as it resulted in a student attending Spanish MT and not Arabic, which shifted rigid categories of what is a "mother tongue", as assumed by the School Ordinance, and thus, oriented from status quo towards a tertiary artefacts design (p. 38). 
The close school-home collaboration in the Spanish MT subject, as opposed to the Spanish ML subject, was further explained by Elena (excerpt 3).

Excerpt 3: $\quad$ Audio-recorded interview with Elena (May 19, 2019).

Researcher: We've understood from, whether it was you or someone else who said this, that when it comes to Modern Languages and Mother Tongue Instruction, that it can be very different, for example, parental contact, well, the type of parental contact you have in these two subjects. Could you describe this?

Elena: $\quad$ Yes, in Modern [Languages], if I call the parents, it's because the student isn't coming; it's about like lack of attendance or not handing in homework, that's all. But for Mother Tongue, parental contact with Mother Tongue is closer because there are many [parents in MT] who can't speak Swedish, so they contact me to be able to have communication with the school or other teachers, so, they use me [laughs] to interpret more or less with Mother Tongue parents. So I don't have a relationship with Modern [Language] students, their parents. In Mother Tongue they... Yesterday a dad called and said "what do you think", not [laughs] "what do you think he should do, he should choose”, because eh now there's a language choice [regarding a modern language] [...] I recommended to the father that he [the son] should take French [as a Modern Language] because he already knows Spanish, and he misses a language or misses being able to learn a new language [if he takes Spanish both in MT and as a Modern Language].

In our interpretation, Elena's retold motive for advising the student to choose French reflects a resourceful view of multilingualism (cf. Ruíz 1984). This stance was shared by all the MT teachers, who strived to provide opportunities for multilingual learning and to include students in their classes beyond what they were obliged to (excerpts 1-3). For example, Malika expressed that "I've told them [the students]: 'You'll have three languages, then you have to choose one more, and you'll have four languages - it's great power. You must come to Mother Tongue"” (Fieldnotes, Feb. 8, 2019). This is, we argue, further indicative of an ethics 
of care (Watkins 2011), where the perceived future prospects of multilingual language learning overruled possible practical problems. Thus, the teachers also ascribed to "longer-term goals" in line with a tertiary artefacts design (Edwards 2011: 38).

The MT teachers' close collaboration with parents/caregivers was also evident from Malika's emphasis on its value in MT Arabic, which she, like Elena, contrasted with ML in French (excerpt 4).

Excerpt 4: Fieldnotes from conversation with Malika after an Arabic MT lesson (February 8, 2019).

Malika knows all the children's parents in Mother Tongue instruction. [...] "If you want the children to like you, you have to know the parents, call, talk, and the children will see that”. Malika considers it to be different in French [as a Modern Language][...]. Malika does not know these parents, compared to the more personal situation in Mother Tongue instruction: "The same goes for the kids. They don't tell [teacher x] or [teacher y], but when I or Omid come, they'll tell what happened, if they have quarreled with someone, they'll tell”. [...] Omid has contact with the fathers, and Malika with the mothers [in MT]. Malika prefers to talk to the mothers [in MT]: "In all cultures, the mother is something extra, I want to talk to the mother".

Excerpt 4 provides insight into the distribution of the extensive parental contacts between the MT teachers. According to Malika, the division of parental contacts between Omid and her was an allocation of workload, which can be viewed as a local system of distributed work and engagement (cf. Edwards 2011). Malika deemed contact with parents in her spare time as part of her professional role and thought it contributed to students' trust in the teachers (excerpt 4). This is not only reflective of an ethos of parental inclusion (Block et al. 2014), but also an ethics of care, in relation to the students and parents (Watkins 2011). Relational agency and care were also contingent upon the fact that many migrant children and their families experienced unstable living conditions, to which the teachers felt obliged to respond.

\subsubsection{Didactic adjustments}

Didactic adjustments relate to the instruction in the MT classrooms. Here, we specifically refer to the preparations for the music and poetry show on International Mother Language Day that we observed. Many students were expected to 
learn relatively challenging literary texts, which entailed hard work, since language proficiency levels varied greatly, but also motivational work by the teacher. Excerpt 5 is from a Spanish MT class where Elena explains why the students should learn a sonnet from Don Quixote for this show. The choice of text illustrates a stark difference between the language and literary use in MT and that in IC, where recently arrived students were exposed to adapted and limited language and literacy in Swedish (Hedman and Magnusson 2021a).

Excerpt 5: $\quad$ Fieldnotes from a Spanish lesson with Elena (February 13, 2019).

Elena: Vamos a leer La poesía de la escuela.

Elena is showing off nice homemade hats that one can wear on International Mother Language Day. She puts one on, and it looks like there are sunbeams coming out of her head. The class talks about International Mother Language Day; that what they are doing now is for that day [...] Elena then explains the text: that it is from Don Quixote, a book by Cervantes, and is the second most translated book in the world, after the Bible; that it has been translated into "all languages", and that Don Quixote is a bit crazy, loco de su dentura. A boy asks if they can read it in Swedish [the students have both a Spanish and a Swedish version of the text], but Elena says, "we speak Spanish" and "Swedish will be on the screen on International Mother Language Day". She turns to me: "It took a lot of time to translate this" [laughter]. Then she asks the children: "What is Mother Language Day?"

A student: The language we speak at home.

Elena: We celebrate Mother Language Day to celebrate that we have the right to read and write our mother tongue, the languages we think and believe in. In this way, it is an important day, International Mother Language Day, just like Women's Day.

A student: Father's day.

Elena: Yes: Father's Day, Mother's Day, Semmel Bun Day [Fat Tuesday] laughter.

Elena motivates the students by letting them know that the original text is wellknown not only in the Spanish-speaking world, but in the whole world, "in all languages”. Elena wants them to read the Spanish version of the text, as "we speak Spanish" (in Spanish MT), although she also translates words and points out that the Swedish translation would be available during the show. The translation could be seen as a translingual-didactic adjustment for inclusion, both to Spanishspeaking students who would benefit from a Swedish translation and to nonSpanish speaking students (see also excerpt 8). 
The subsequent question about International Mother Language Day brought a language as right framework (Ruíz 1984) to the fore. It was made explicit in Elena's statement that "we have the right to read and write in our mother tongue" and was further reinforced in the empowering reference to International Women's Day.

The choice of a modern adaptation (La poesía de la escuela) of the original text in Español antiguo forms another didactic adjustment. Nevertheless, it took much effort to reformulate and explain many of the difficult words, and Elena needed to accommodate to students' different language proficiency levels. Excerpt 6 is from the end of a lesson, when she asked three 1st grade students (ages 6-7 years) to stay longer and read the text. The excerpt exemplifies Elena's supple way of convincing the young students to rehearse the text yet another time.

Excerpt 6: Fieldnotes from an MT Spanish lesson with Elena and 1st grade students (February 14, 2019).

Elena ends the lesson for some, but three boys stay. Elena says "Feliz Valentin", when the other children leave. A boy wants biscuits and does not want to read. Elena says she has no biscuits today. Elena scratches a boy on the back, and they talk for a while about his perrito [dog], but the boys still do not want to read again.

Elena puts three chairs in front of the white board [with the text] and wants them to read one last time. One of the boys wants to climb the chair. Elena asks him to behave: Hay que comportarse bien [...] Another boy also wants her to scratch his back. Elena stands up with the board/the text behind her and tries to read by heart so that the boys can see for themselves whether she reads correctly or not. The boy who wanted to climb the chair is allowed to hold the paper in front of Elena's eyes so that she cannot see. She reads what she remembers from the text and asks afterwards: "Did I know it or not?"

Boys: No!

Elena: Should I read again?

Boys: Yes!

Now everyone reads the text together; they do a high five. Here, she has in a clever and playful way made them focus on the task. After the lesson, Elena is happy that the children read the text once more.

We need to understand this excerpt on the basis of MT being a non-mandatory subject that is taught after a long day of school, here, in the middle of the dark 
Swedish winter. It is thus a challenging endeavor to make the very young children stay to do additional work on this demanding text. Elena had to be flexible, creative and understanding in order to engage them at such a late hour. Through playfulness and finesse, she succeeded. The episode further took place during extra time in relation to the limited MT teaching hours, which Elena found necessary to be able to prepare the students properly for the upcoming event.

In sum, excerpts 5-6 give a glimpse into the long and laborious preparations in class, comprising necessary difficult and creative work to get all students to participate. One can conclude that it is not an easy task to deliver an aestheticliterary performance; rather, it relies on the MT teachers' high expectations and dedicated collaboration. Importantly, the work in these individual lessons (excerpts 5-6) was aimed for a shared educational goal, building on relational agency and expertise among the MT teachers.

\subsubsection{Adjustments with respect to an ethos of inclusion}

Another focal point in our analyses was the MT teachers' adjustments for the purposes of obtaining linguistic inclusion and parental involvement. An inclusive stance was visible in the choice of teaching material when Malika introduced a song celebrating an unspecified Arabic-speaking nation, considering that her students originated from various Arabic-speaking countries. The text was in Modern Standard Arabic (MSA), which the students thus encountered in MT (excerpt 7).

Excerpt 7: $\quad$ Fieldnotes from preparations in the MT preschool class in Arabic with Malika (February 8, 2019).

Today, the students start practicing a song for International Mother Language Day, and they sing along in a YouTube clip shown on the smartboard. The song is known as a tribute to a nation (unspecified, relates to any Arabic-speaking countries, as I understood it, and Malika emphasizes to us afterwards that the song may also apply to Sweden). [...] The song is part of the arabe litteraire tradition, and she gives us a translation. The melody is catchy, and Malika thinks it suits the younger children. [...]

Malika's stance is in line with Elena's emphasis on the worldwide reach of Don Quixote (excerpt 4). As with the song based in the arabe litteraire tradition and Don Quixote, the MT teachers provided opportunities to engage with literature. Malika and Elena recounted that they contributed children's literature in Romance languages and Arabic to the supplies at Chestnut from their vacations abroad. 
These joint teacher efforts - to make their work matter to all students, to invest in their students' language and literature learning, and to uphold close schoolhome relations - are reflective of a shared view on the dynamics of their professional roles as MT teachers. This is, we argue, both an effect of and a prerequisite for their collaborative agency.

Also, the recently arrived students in the ICs participated in the musical performance, in Swedish, in addition to other languages. Their participation entailed a collaboration between the MT teachers and the SSL teachers in the ICs, indicating relational expertise and agency across subjects/disciplines (Edwards 2011). The following fieldnotes (excerpt 8) were taken during the actual musical show, as the children performed the songs and poems that they had been working on for a long time. Omid opened the event by thanking the students, teachers and school management.

Excerpt 8: Fieldnotes from the celebration of International Mother Language Day, February 22, 2019.

When everyone is seated in the school's assembly hall, Omid opens the celebration with a speech. He welcomes everyone in Arabic (Classic Arabic, we'll find out later). Other teachers welcome everyone in Catalan, Spanish and Italian. Omid thanks students, teachers and school management for their commitment. "A mosaic consists of small pieces that together form a nice pattern", says Omid, "and the pieces are you. We are our school, and our school makes a difference". What is said in languages other than Swedish is translated into Swedish on a screen.

Omid: International Mother Language Day has a purpose, and now we will hear it in six languages from the mother tongue ambassadors. Six children read aloud in Arabic, English, Swedish, Spanish, Italian and Portuguese. Then, the introductory classes come up on the stage with flags and sun hats, together with the teacher of Swedish as a second language. Omid: Intro classes, go ahead. The intro classes are so fantastic, from all corners of the world. What unites us is Swedish, and now we have the honor to say a sentence in Swedish and another language. [...] Malika and her group of about 20 children sing the song in Arabic about love for a nation with flags in hand. Malika and Omid sing along - Omid on his knees. He seems to make an effort to give the song its right expression. 


\section{[...]}

Five middle school students read the sonnet Don Belianís of Greece to Don Quixote of the Mancha (from Elena's class). A translation in Swedish is shown on the screen together with Pablo Picasso's illustrations.

[...]

Four students sing the song The home of the fish with Omid in Arabic. [Later, the song comes up in a conversation with Omid and Malika, who connect it to being a refugee, to ask where one's home is]. After that, the following text appears on the screen, which we have heard Omid quote several times: If you speak to a man in a language he understands, it goes to his head. If you talk to him in his language, it goes to his heart (Nelson Mandela). Finally, the principal steps up on the stage and says: "Wow, it's fantastic what you dare to and can do. I'm proud to be the principal, you know that".

The performance presents a variety of languages and represents a great deal of effort from students and teachers. With an inclusive "we", Omid foregrounds Swedish in the presentation of the students in the ICs by stating that "what unites us is Swedish". His statement both implies and is contingent upon that most of "us" at Chestnut speak languages other than Swedish. As evident in excerpt 8, translations into Swedish of the sonnet from Don Quixote and the Arabic poem. The home and the fish were displayed to also include non-Spanish and non-Arabic speakers. As explained by Omid afterwards, the latter song mirrored vulnerable trajectories of migration as a shared experience at Chestnut.

Importantly, this shared experience indicates that the audience did not necessarily consist of students encountering the "linguistic Other" (cf. Flores and Rosa 2015). As stated, most students were entitled to MT, although not everyone studied it. The principal's participation, in conjunction with Omid's empowering discourse on the students and the school as a unity that "can make a difference", turned this event into a celebration of the school and all its students. Such an acknowledgement of "diverse voices and perspectives so that all children feel they belong and can contribute" could be viewed as a manifesto of an ethos of inclusion (Block et al. 2014: 1340).

The emphasis in this paper is, however, not on the musical show per se, but on what it contributed in terms of afforded opportunities to gather around and learn various works of literature and poetic language and of linguistic inclusion. Although this particular celebration was restricted to the course of a morning, the performance formed an incentive for more enduring and effortful work on 
advanced literary content. It would thus be simplistic to view this annual event as mere celebration of multiculturalism or lip service to multilingualism (Janks 2013). One reason is that the event was arranged by the MT teachers themselves; another is that it involved teaching and learning. Our analysis of the event - from a teacher and teaching perspective (cf. Dewilde et al. 2021) - also reveals relational agency emerging from shared expertise, including the teachers' in-depth knowledge of the students and their families. Further, the show mirrors efforts beyond the necessary, thus representing artefacts beyond the status quo concerning what could be possible (Edwards 2011). The significance of this team is further discussed in the final concluding section.

\section{Concluding discussion}

To better understand the role of the MT teacher team, the existence of such a locally employed team needs to be calibrated against what is usually the case in Swedish schools. As outlined above, MT teachers tend to not be employed by the schools in which they are thus not well-integrated (SOU 2019:18). In this case, the MT teacher team was able to take an opportunity to transgress boundaries beyond their respective MT classes, something that ambulating teachers would be less likely to succeed at doing.

This indicates the importance of both the relational and contextual dimensions of these teachers' opportunities to exert agency (cf. Edwards 2011; Priestly et al. 2015) vis-à-vis the students' linguistic repertoires and educational needs. Here, the teachers' responsive collaboration connected with children and parents of diverse language backgrounds in a locally practiced multilingual policy (Bonacina-Pugh 2020: 434). This policy was thus shaping and being shaped by Chestnut as a contact zone for linguistic diversity (cf. Pratt 1991). A diverse interactional space does, however, not automatically render its interactants an openness to diversity (cf. Canagarajah and Matsumoto 2017). At Chestnut, such an openness was visible through observed expressions of multilingualism as a resource and a right (see Hult and Hornberger 2016; Ruíz 1984). In fact, the teachers' relational agency and distributed expertise implied extended access to language learning for the migrant students both through the teachers' adjustments, as analyzed above, and through the endeavors leading up to the performance. Their agency thus represented the formulation of an "imagined world" (Edwards 2011: 36) in relation to governing documents, situating multilingual competence at the center. Furthermore, the collective care that we observed with regard to the students' multilingual development through extensive teacher adjustments, creativity, strategic work and close schoolhome relations also reflects an ethos of inclusion (cf. Block et al. 2014). This ethos, we argue, emerged from intertwined relational and situated agencies not only among 
the MT teachers, but also in relation to the school management, other teachers, parents and students.

Moreover, through the MT subject, the MT teachers created possibilities for students to engage with literary texts and language for literary purposes. These experiences stood in stark contrast to the less advanced Swedish literacy in the IC classes (despite high-quality teaching in these beginner classes, Hedman and Magnusson 2021a). A space for literature and uncommon sense registers, required in the students' education (Halliday 1993), was instead opened up by the MT teachers. Their responsive professional action (Edwards 2011: 29) thus accomplished extended access to both language and literary learning for their students, pointing to a vital educational function of the MT subject in this context.

However, several aspects relating to the ecology of the school warrant further examination. One question is, for example, how ideologies, expertise, strategies and regulations interact and form incentives to recruit locally employed MT/ multilingual teachers. The role of school management, which actually forms part of it, is also important to explore further. In this case, we find the relative autonomy of the MT teachers in shaping their own practice to be crucial, which here reflected more than a mere laissez-faire approach of the principal. Instead, we find that the locally employed MT teacher team formed a central part of Chestnut, and for home-school relations, on which the school and the principal were depending. The MT teachers' work was thus encouraged and supported by - as well as entangled with - the school's management. This is most likely a prerequisite for the aforementioned accomplishments of this particular approach.

This paper thus contributes new knowledge on the role of relational teacher agency and distributed expertise, as well as interconnectedness with an ethics of care (Watkins 2011) for linguistic adjustments made by multilingual teachers in a linguistically diverse context. In an era of increased top-down systems of control in education (Wells 2017), we emphasize the need for acknowledging and more carefully scrutinizing collaborative agency and expertise at the local level. Such agentive acts among multilingual language teachers hold important potential for the development of practice, which has relevance to other educational settings comprising migrant learners in trajectories of vulnerability, outside of Sweden.

\section{Appendix: Transcripts in Swedish.}

[MM = modersmålsundervisning $]$

Excerpt 1. Audio-recorded researcher talk with Malika (from the classroom walking tour; March 19, 2019). 
Forskare: Finns det exempel på när det har blivit olika, studiehandledning i ett språk och modersmål i ett annat, för samma elev?

Malika: Det finns på arabiska, mycket.

Forskare: Berätta.

Malika: Vi har [elevs namn] till exempel han har kommit ny till oss, och han kan mycket svenska för att han har varit också i intro [Introduktionsklass] i svenska som andraspråk. Sen, nu vi ger honom engelska och arabiska för att han kan så mycket engelska så bägge två [skratt] för att han kan inte förstå SO och NO på svenska, så vi ger studiehandledning på andra språk.

Forskare: På både arabiska och engelska?

Malika: Ja.

Forskare: Är det du som gör det?

Malika: Jag och Omid, jag har inte så mycket tid nu. [...]

Forskare: Men läser han då arabiska i modersmål?

Malika: Han kommer till modersmål i arabiska, och han kommer också till modersmål i engelska om han har tid.

Forskare: Aha både ock, får han det?

Malika: Ja, jag har också en från [arabisktalande land], han kommer till arabiska och franska i modersmål.

Forskare: Men det är jättebra, då tycker ni det är...

Malika: Jag sa till honom om du åker till [namn på land], det räcker inte med arabiska, för att alla papper och skyltar, och folk blandar också mycket med franska. Du behöver två stycken. [skratt]

Forskare: Jaja.

Malika: $\quad$ Så jag sa du kan komma till mig [i modersmålslektioner i franska].

Excerpt 2: Fieldnotes from conversation with Elena (February 14, 2019).

Elena berättar om eleverna som har arabisktalande föräldrar men som har spanska i modersmålsundervisningen och i studiehandledning. En pojke hade både arabiska och spanska i modersmålsundervisningen i höstas. Men eftersom de har [en viss] dialekt förstår pojken varken Malika eller Omid enligt Elena, så föräldrarna vill att han fortsätter med spanska. Pappan har tydligen bott flera år i Spanien så föräldrarna är också spansktalande, men inte svensktalande. 
Excerpt 3. Audio-recorded interview with Elena (May 19, 2019).

Forskare: Vi har förstått från, om det var du eller någon annan som sa, att när det gäller moderna språk och modersmål, att det kan skilja sig väldigt mycket, till exempel föräldrakontakten, asså den typ av föräldrakontakt man har i de här två ämnena. Skulle du kunna beskriva det?

Elena: Ja i moderna [moderna språk], om jag ringer några föräldrar, det är om eleven kommer inte, det är typ frånvaro eller lämnar inte in läxorna det är allt. Men modersmål, kontakt med modersmål är mer nära eftersom det är många [föräldrar i MM] som kan inte svenska så de tar mig för att kunna ha kommunikation med skolan eller andra lärare, så de använder mig [skratt] för att tolka eller så, med modersmålsföräldrar. Så jag har en relation inte med moderna [språk] elever, som är föräldrar. På modersmål de... igår ringde en pappa och sa "vad tycker du?", inte [skratt] "vad tycker du han ska göra han ska välja", för att eh nu finns språkval för att välja [till moderna språk] [...] Jag rekommenderade pappan att han [sonen] skulle ta franska [som moderna språk] för att han kan redan spanska och han missar ett språk eller missar att kunna lära sig ett nytt språk [om han studerar spanska både i MM och moderna språk].

Excerpt 4. Fieldnotes from conversation with Malika after an Arabic MT lesson (February 8, 2019).

Malika känner alla barnens föräldrar i modersmålsundervisningen. ”Om du vill att barnen ska tycka om dig, måste du känna föräldrarna, ringa, prata och barnen ser det”. Malika ser att det är en annan sak i franska [som modernt språk]. [...] Malika känner inte de föräldrarna till skillnad från vad som är fallet i modersmålsundervisningen: "Samma gäller för barnen. De berättar inte för [lärare x] eller [lärare y], men när jag eller Omid kommer berättar de, vad som har hänt, har du bråkat med någon, de berättar”. [...] Omid har kontakt med papporna, och Malika med mammorna [i MM]. Malika vill helst prata med mammorna [i modersmålsundervisningen]: "I alla kulturer är mamma något extra, jag vill prata med mamman”.

Excerpt 5: Fieldnotes from a Spanish lesson with Elena (February 13, 2019).

Elena: Vamos a leer La poesía de la escuela. 
Elena visar fina egengjorda hattar som de ska ha på sig på Internationella modersmålsdagen. Hon tar själv på en, och det ut som solstrålar kommer ut från huvudet.

De pratar om den internationella modersmålsdagen, att det de gör nu är för den dagen. [...] Elena förklarar sedan texten, att den är från Don Quixote, en bok av Cervantes och är den andra mest översatta boken i världen efter Bibeln, översatt till "alla språk”, och att Don Quixote är lite tokig, loco de su dentura. En pojke frågar om de kan läsa på svenska [de får både en spansk och svensk version av texten] men Elena säger "vi pratar på spanska", "svenska kommer att vara på skärmen på modersmålsdagen". Hon vänder sig till mig: "Det tog massor av tid att översätta detta" [skratt]. Sedan frågar hon barnen: "Vad är modersmålsdagen?”.

Elev: Det språk vi pratar i hemmet.

Elena: Vi firar modersmålsdagen för att fira att vi har rätt att läsa och skriva vårt modersmål, de språk vi tänker och tror på. På så sätt är det en viktig dag, modersmålsdagen, precis som kvinnodagen.

Elev: Farsdag.

Elena: Ja farsdag, morsdag, semmeldagen [fettisdagen]. Skratt.

Excerpt 6: Fieldnotes from an MT Spanish lesson with Elena and $1^{\text {st }}$ grade students (February 14, 2019).

Elena avslutar lektionen för några, men tre pojkar är kvar. Elena säger: Feliz Valentin när de andra barnen går. En pojke vill ha kex och vill inte läsa. Elena säger att hon inte har något kex idag. Elena kliar en pojke på ryggen och de pratar en stund om hans perrito [hund], men pojkarna vill ändå inte läsa en gång till.

Elena tar fram tre stolar framför tavlan [med texten], vill få dem att läsa en sista gång. En av pojkarna vill klättra på stolen. Elena ber honom uppföra sig: Hay que comportarse bien. [...] En pojke till vill också bli kliad på ryggen. Elena ställer sig mot pojkarna med tavlan/texten bakom sig och försöker läsa utantill så att pojkarna själva kan se om hon läser rätt eller inte. Pojken som ville klättra på stolen får hålla papperet framför Elenas ögon så att hon inte kan se. Hon läser vad hon kommer ihåg av texten och frågar efteråt: "Kunde jag eller kunde jag inte?”

Pojkarna: Nej!

Elena: Ska jag läsa igen?

Pojkarna: Ja! 
Alla läser nu texten tillsammans, de gör high five. Här har hon på ett smart och lekfullt sätt fått dem att fokusera på uppgiften. Efter lektionen är Elena glad över att barnen läste texten igen.

Excerpt 7: Fieldnotes from preparations in the MT preschool class in Arabic with Malika (February 8, 2019).

I dag börjar eleverna att öva en sång till modersmålsdagen, och de sjunger med i ett YouTube-klipp visat på smartboard. Sången är känd som en hyllningssång till sin nation (ospecificerad, rör arabisktalande länder, uppfattade jag det som, och Malika betonar för oss efteråt att den även kan gälla Sverige). [...] Sången ingår i traditionen Arabique littéraire och hon ger oss en översättning. Melodin är catchy och Malika menar att den passar de yngre barnen. [...]

Sen jobbar de med flaggor till modersmålsdagen, både den svenska flaggan och en flagga från det land som eleverna eller deras föräldrar kommer ifrån. En elev säger att han inte vill göra den svenska flaggan "för den kan han redan" men Malika betonar att "vi vill det".

Excerpt 8: Fieldnotes from the celebration of International Mother Language Day (February 22, 2019).

När alla har satt sig i skolans aula inleder Omid firandet med ett tal. Han hälsar alla välkomna på arabiska (klassisk, får vi sedan veta). Övriga lärare hälsar alla välkomna på katalanska, spanska och italienska. Omid tackar elever, lärare och skolledning för deras engagemang. "En mosaik består av små bitar som tillsammans bildar ett fint mönster”, säger Omid "och bitarna är ni. Vi är vår skola och vår skola gör skillnad”. Det som sägs på andra språk än svenska finns översatt till svenska på en skärm.

Omid: Modersmålsdagen har ett syfte och nu ska vi få höra det på sex språk av modersmålsambassadörerna. Sex barn läser upp syftet på arabiska, engelska, svenska, spanska, italienska och portugisiska. Sedan kommer Introduktionsklasserna upp på scenen med flaggor och solhattar tillsammans med läraren i svenska som andraspråk. Omid: Introklasserna, varsågoda. Introklasserna som är så fantastiska, från världens alla hörn. Det som förenar oss är svenskan och nu har vi äran att säga något på svenska och modersmålet, varsågoda. Eleverna säger varsin mening på svenska och ett annat språk. [...]

Malika och hennes grupp med ca 20 barn sjunger sången på arabiska om kärlek till en nation. Flaggor i händerna. Malika och Omid sjunger med - Omid på knä. Han verkar lägga sig vinn om att sången ska få sitt rätta uttryck.

[...]

Fem mellanstadieelever läser sonetten Riddar Belianís av Grekland till Don Quijote av La Mancha (från Elenas klass). En översättning visas på svenska på skärmen tillsammans med Pablo Picassos illustrationer. 
[...]

Fyra elever sjunger sången Fiskens hem med Omid på arabiska. Sången kommer senare upp i samtal med Omid och Malika, som kopplar den till att vara flykting, att fråga var ens hem finns. Därefter kommer följande text upp på skärmen, som vi hört Omid citera flera gånger: Om du talar med en man på ett språk han förstår, går det till hans huvud. Om du pratar med honom på hans språk, går det till hans hjärta (Nelson Mandela). Slutligen kliver rektor upp på scenen, och säger "wow, det är häftigt vad ni vågar och kan. Jag är stolt över att vara rektor, det vet ni”.

Acknowledgments: This project was supported by the Erik Wellander Foundation.

\section{References}

Blackledge, Adrian \& Angela Creese. 2017. Translanguaging and the body. International Journal of Multilingualism 14(3). 250-268.

Block, Karen, Suzanne Cross, Elisha Riggs \& Lisa Gibbs. 2014. Supporting schools to create an inclusive environment for refugee students. International Journal of Inclusive Education 18(12). 1337-1355.

Bonacina-Pugh, Florence. 2012. Researching 'practiced language policies': Insights from conversation analysis. Language Policy 11(3). 213-234.

Bonacina-Pugh, Florence. 2020. Legitimizing multilingual practices in the classroom: The role of the 'practiced language policy'. International Journal of Bilingual Education and Bilingualism 23(4). 434-448.

Bourdieu, Pierre. 1977. The economics of linguistic exchange. Social Science Information 16(6). 645-668.

Canagarajah, Suresh \& Yumi Matsumoto. 2017. Negotiating voice in translingual literacies: From literacy regimes to contact zones. Journal of Multilingual and Multicultural Development 38(5). 390-406.

Copland, Fiona \& Angela Creese. 2015. Linguistic ethnography. Collecting, analyzing and presenting data. Los Angeles: Sage.

Creese, Angela, Jaspreet Kaur Takhi \& Adrian Blackledge. 2015. Metacommentary in linguistic ethnography. In Julia Snell, Sara Shaw \& Fiona Copland (eds.), Linguistic ethnography, 266-284. New York: Palgrave Macmillan.

Dewilde, Joke, Ole Kolbjørn Kjørven \& Thor-André Skrefsrud. 2021. Multicultural school festivals as a creative space for identity construction - The perspective of minority parents. Intercultural Education 32(2). 212-229.

Edwards, Anne. 2005. Relational agency: Learning to be a resourceful practitioner. International Journal of Educational Research 43(3). 168-182.

Edwards, Anne. 2010. Being an expert professional practitioner: The relational turn in expertise. Dordrecht: Springer.

Edwards, Anne. 2011. Building common knowledge at the boundaries between professional practices: Relational agency and relational expertise in systems of distributed expertise. International Journal of Educational Research 50(1). 33-39. 
Emerson, Robert M., Rachel I. Fretz \& Linda Shaw. 2011. Writing ethnographic fieldnotes. Chicago: University of Chicago Press.

Flores, Nelson \& Jonathan Rosa. 2015. Undoing appropriateness: Raciolinguistic ideologies and language diversity in education. Harvard Educational Review 85(2). 149-171.

Ganuza, Natalia \& Christina Hedman. 2015. Struggles for legitimacy in mother tongue instruction in Sweden. Language and Education 29(2). 125-139.

Ganuza, Natalia \& Christina Hedman. 2019. The impact of mother tongue instruction on the development of biliteracy: Evidence from Somali-Swedish bilinguals. Applied Linguistics 40(1). 108-131.

Giddens, Anthony. 1984. Constitution of society: Outline of the theory of structuration. Cambridge: Polity Press.

Halliday, Michael. 1993. Towards a language-based theory of learning. Linguistics and Education 5. 93-116.

Hedman, Christina \& Ulrika Magnusson. 2021a. Introductory classes for newcomer primary school students in Sweden: Pedagogical principles and emotional understanding. Multicultural Education Review 13(1). 85-105.

Hedman, Christina \& Ulrika Magnusson. 2021b. Constructing success and hope among migrant students and families: A mother tongue teacher's didactic narratives. Language \& Communication 77. 93-105.

Horner, Bruce, Min-Zhan Lu, Jacqueline Jones Royster \& John Trimbur. 2011. Opinion: Language difference in writing: Toward a translingual approach. College English 73(3). 303-321.

Hult, Francis M. 2012. English as a transcultural language in Swedish policy and practice. TESOL Quarterly 46(2). 230-257.

Hult, Francis M. \& Nancy Hornberger. 2016. Re-visiting orientations to language planning: Problem, right, and resource as an analytical heuristic. Bilingual Review 33(3). 30-49.

Janks, Hilary. 2013. Critical literacy in teaching and research. Education Inquiry 4(2). 225-242.

Miller, Donna \& Monica Turci. 2007. Language and verbal art revisited: Linguistic approaches to the study of literature. London: Equinox.

Ministry of Education and Research. 2010. The Swedish education act. SFS 2010:800. Stockholm: Utbildningsdepartementet.

Ministry of Education and Research. 2011. School ordinance. SFS 2011:185. Stockholm: Utbildningsdepartementet.

Nikolajeva, Maria. 2014. Reading for learning: Cognitive approaches to children's literature. Amsterdam: John Benjamins.

Nussbaum, Martha. 1997. Cultivating humanity. A classical defence of reform in liberal education. Cambridge: Harvard University Press.

Pratt, Mary Louise. 1991. Arts of the contact zone. Profession 91. 33-40.

Priestly, Mark, Gert Biesta \& Sarah Robinson. 2015. Teacher agency: An ecological approach. London: Bloomsbury Academic.

Rosén, Jenny, Boglárka Straszer \& Åsa Wedin. 2020. Användning av språkliga resurser i studiehandledning på modersmålet [The use of language resources in study guidance in the mother tongue]. Pedagogisk forskning i Sverige 25(2-3). 26-48.

Ruíz, Richard. 1984. Orientations in language planning. NABE: The Journal for the National Association for Bilingual Education 8(2). 15-34.

Shaw, Sara, Fiona Copland \& Julia Snell. 2015. An introduction to linguistic ethnography: Interdisciplinary exploration. In Fiona Copland, Sara Shaw \& Julia Snell (eds.), Linguistic ethnography: Interdisciplinary explorations, 1-13. New York: Palgrave McMillan. 
SOU. 2019. För flerspråkighet, kunskapsutveckling och inkludering. Modersmålsundervisning och studiehandledning på modersmål. [For multilingualism, knowledge development and inclusion. Mother tongue instruction and study guidance in the mother tongue]. Stockholm: Utbildningsdepartementet.

Straszer, Boglárka \& Åsa Wedin (eds.). 2020. Modersmål, minoriteter och mångfald: i förskola och skola [Mother tonguge, minorities and diversity; in preschool and school]. Lund: Studentlitteratur.

Swedish National Agency for Education. 2019. Studiehandledning på modersmålet - att stödja kunskapsutvecklingen hos flerspråkiga elever. [Study guidance in the mother tongue]. Lund: Skolverket.

Szabó, Tamás Péter. 2015. The management of diversity in schoolscapes: An analysis of Hungarian practices. Apples - Journal of Applied Language Studies 9(1). 23-51.

Taylor, Sandra \& Ravinder Kaur Sidhu. 2012. Supporting refugee students in schools: What constitutes inclusive education? International Journal of Inclusive Education 16(1). 39-56.

Thomas, Wayne \& Virginia Collier. 2002. A national study of school effectiveness for language minority students' long term academic achievement: Final Report. Available at: http://crede. berkeley.edu/research/lla/1.1_final.html.

Wartofsky, Marx. 1973. Models. Dordrecht: Reidel.

Watkins, Megan. 2011. Teachers' tears and the affective geography of the classroom. Emotion, Space and Society 4(3). 137-143.

Wells, Cacey. 2017. Understanding issues of control in top-down management pedagogies. Power and Education 9(3). 192-201. 